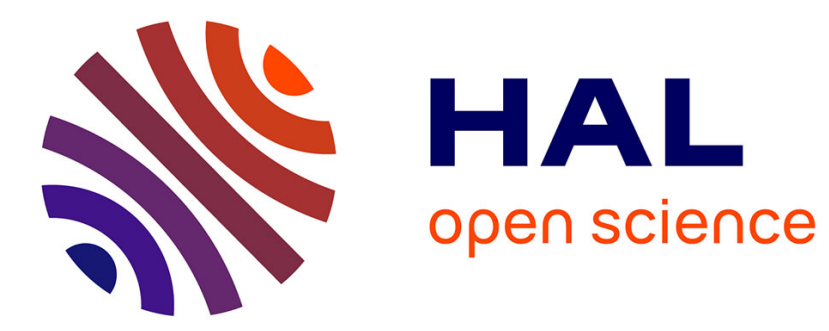

\title{
Income taxation, labour supply and housework: a discrete choice model for French couples
}

\author{
Jan Kabatek, Arthur van Soest, Elena Stancanelli
}

\section{To cite this version:}

Jan Kabatek, Arthur van Soest, Elena Stancanelli. Income taxation, labour supply and housework: a discrete choice model for French couples. Labour Economics, 2014, 27, pp.30-43. 10.1016/j.labeco.2014.01.004 . hal-00966801

\section{HAL Id: hal-00966801 https://hal.science/hal-00966801}

Submitted on 27 Mar 2014

HAL is a multi-disciplinary open access archive for the deposit and dissemination of scientific research documents, whether they are published or not. The documents may come from teaching and research institutions in France or abroad, or from public or private research centers.
L'archive ouverte pluridisciplinaire HAL, est destinée au dépôt et à la diffusion de documents scientifiques de niveau recherche, publiés ou non, émanant des établissements d'enseignement et de recherche français ou étrangers, des laboratoires publics ou privés. 


\title{
Income taxation, labour supply and housework:
}

\section{A discrete choice model for French couples*}

\section{Jan Kabátek $^{\mathrm{a}}$, Arthur van Soest ${ }^{\mathrm{a}}$ and Elena Stancanelli ${ }^{\mathrm{b}}$}

${ }^{a}$ Netspar, Tilburg University and IZA. Tilburg University, P.O. Box 90153, 5000 LE Tilburg, the Netherlands.

${ }^{\mathrm{b}} \mathrm{CNRS}$, Sorbonne Economics Research Center, and Paris School of Economics, and IZA.

106-112 Boulevard de l'Hopital 75013 Paris, France

\begin{abstract}
Earlier studies suggest that income taxation may affect not only labour supply but also domestic work. Here we investigate the impact of income taxation on partners' labour supply and housework, using data for France that taxes incomes of married couples jointly. We estimate a household utility model in which the marginal utilities of leisure and housework of both partners are modelled as random coefficients, depending on observed and unobserved characteristics. We conclude that both partners' market and housework hours are responsive to changes in the tax system. A policy simulation suggests that replacing joint taxation of married spouses' incomes with separate taxation would increase the husband's housework hours by $1.3 \%$ and reduce his labour supply by $0.8 \%$. The wife's market hours would increase by $3.7 \%$, and her housework hours would fall by $2.0 \%$.
\end{abstract}

\footnotetext{
* We are grateful to the French Agence National de la Recherche (ANR) for financial support. Earlier versions of this paper were presented at a Manheim conference on tax simulation models, an IZA workshop on income taxation, a Nice workshop on the economics of couples, the feminist economics annual conference in Turin 2008, and the International Association for Time Use Research annual conference in Paris in 2010 and at seminars given at San Diego State University, Cergy Pontoise University, Rockwool Foundation Copenhagen, Siena University, and Manheim University. We thank all participants for comments. In particular, we are grateful to Ian Walker and an anonymous reviewer for very helpful and constructive suggestions.
} 


\section{Highlights:}

-Joint taxation of spouses' incomes is likely to discourage female labour supply.

-Joint taxation is likely to reinforce female specialization in house work.

-We study how switching to independent taxation affects spouses' time allocation.

-We find that the husband's house work increases while the wife's housework drops.

-We conclude that the wife's labour supply increases while the husband's hours fall.

Keywords: time use, taxation, discrete choice models

JEL classification: J22, H31, C35 


\section{Introduction}

Theoretical studies of income taxation conclude that income taxes may affect not only individual labour supply but also the amount of domestic work produced within the household. Income taxation is likely to affect labour supply and housework hours in opposite directions because downward changes in the individual rewards from work reduce the individual opportunity cost of housework and thus, housework becomes more attractive than market work. There is limited empirical evidence on this issue. This paper adds to the literature by estimating a discrete choice model of both partners' market and housework hours. Using these estimates, we simulate how a change from joint to separate taxation of married spouses' incomes affects spouses' hours of market and non-market work. This is especially interesting since France is one of the few OECD countries that still taxes the incomes of married couples jointly.

Apps and Rees $(1988,1999,2011)$ argue that although household production is not taxed (which is unavoidable since its output cannot be observed), the taxation of income is likely to affect not only labour supply but also housework hours of spouses. In particular, married women's labour supply is likely to increase when replacing joint taxation by separate income taxation while housework hours are expected to fall. ${ }^{1}$ Leuthold (1983) estimated the tax elasticities of housework of husband and wife in one and two-earner US households, using a single equation framework, and found that (joint) income taxation increases housework hours of women and reduces housework hours of men. Gelber and Mitchell (2012), focusing on American single women, concluded that when the economic rewards for participating in the labour force increase, single women's market work increases and their housework decreases. Rogerson (2009) examined the effects of taxation on housework and labour supply in the US and Europe from a macroeconomic perspective, and found that when accounting for

\footnotetext{
${ }^{1}$ See also Kleven et al. (2010) for a recent treatment of the optimal taxation of couples. Alesina et al. (2011) analyze how applying different income tax rates for secondary and primary earners ("selective" taxation) can affect the distribution of market work and housework within the household.
} 
home production, the elasticity of substitution between consumption and leisure becomes almost irrelevant in determining the response of market hours to higher taxes.

In this paper we estimate a discrete choice model of both partners' market labour supply and housework hours. Partners' time allocation choices are modelled as the outcome of maximizing a household utility function which includes household net income among its arguments. The model accounts for corner solutions (non-participation) in the labour market as well as non-participation in housework. Fixed costs of paid work are also incorporated. To approximate continuous hours decisions, each household's choice set is discretized and has 2,401 points. The use of a discrete choice specification enables us to incorporate non-linear taxes and welfare benefits.

The model is estimated on data drawn from the 1998-1999 French Time Use Survey. This survey has the advantage of covering a period during which the incomes of French married spouses were taxed jointly and the incomes of cohabiting partners' were taxed separately. Moreover, a time diary was collected for both partners in the household on the same day, which was chosen by the interviewer - in addition to a standard household questionnaire and an individual questionnaire. We observe both partners' market labour supply, housework hours, individual earnings, and household income, as well as the presence and age of children and other individual and household characteristics.

We find positive own net wage elasticities of market work (equal to 0.20 for the male partner and 0.55 for the female partner) and negative own wage elasticities of housework hours (equal to -0.34 for the male partner and -0.36 for the female partner). An increase in the partner's wage rate reduces own market hours and increases own housework hours. These cross effects are smaller though than the own-wage effects, as usually found for market work. Own and cross-wage effects are larger for the wife's market hours than for the husband's, as it is often found in empirical labour supply studies. 
Finally, we simulate the effects of a shift from the current system of joint taxation of married spouses' incomes to separate income taxation. ${ }^{2}$ Joint taxation of spouses' incomes is mandatory in France. Separate income taxation is applied in most OECD countries, though in some countries (for example, the US and Spain), married couples have the option to choose between separate or joint taxation of their incomes. In line with the theoretical expectations, we find that replacing joint taxation of married spouses' incomes with separate taxation would lead to opposite effects for the husband (often the main earner) and the wife (usually the secondary earner): her labour supply would increase while his would fall; and her housework would fall while his would increase. We conclude that replacing joint taxation with separate taxation of married spouses' incomes would increase the wife's participation in paid work by 2.3\%-points and her average market hours by $3.7 \%$, while her housework hours would drop by $2.0 \%$. The husband would partly compensate for the changes in the wife's time allocation by increasing his housework hours by $1.3 \%$ and reducing his market hours by $0.8 \%$. These effects, though statistically significant, represent only a small step towards balancing market and non-market work of the husband and the wife.

The structure of the paper is as follows. The model is presented in Section 2. Section 3 provides an overview of the French income tax system. The data are described in Section 4. The estimation results and the simulations are discussed in Section 5. Section 6 concludes.

\footnotetext{
${ }^{2}$ This extends the work of, for example, Steiner and Wrohlich (2004) and Callan et al. (2009), who estimated the influence of a similar reform of income taxation for Germany and Ireland, respectively, but only looked at market work of the two partners. . However, we leave the nature of the welfare system unchanged which is such that welfare payments are means-tested against total household income for both married and cohabiting couples and may, therefore, discourage labour supply of the secondary earner in the household (usually the female partner).
} 


\section{The discrete choice model}

Our model is an extension of the unitary discrete choice model of household labour supply of van Soest (1995). ${ }^{3}$ Here we allow individuals in a couple to choose between market work, housework, and leisure. Conventional models allow individuals to choose between market work and everything else, thus treating housework as "pure" leisure. In our model household utility depends on both partners' time allocation and on after-tax household income. This last varies with the allocation of hours of market work chosen by the partners and their gross wage rates, given the tax and benefits system. We also specify fixed costs of market work and allow for unobserved heterogeneity in partners' preferences. The choice set is discretized and includes an error term that is specific to each possible choice under a random utility framework.

\section{Theoretical set up}

Formally, let $m$ denote the 'husband' and $f$ the 'wife' (naming for the sake of simplicity, the female partner as the 'wife' and the male partner as the 'husband', regardless of the couple marital status), let $t_{m}^{l}$ and $t_{f}^{l}$ be the leisure hours of husband and wife, $t_{m}^{w}$ and $t_{f}^{w}$ their labour supplies, and $t_{m}^{h}$ and $t_{f}^{h}$ their housework hours. The utility maximized by the couple household is a function of partners' labour supply, housework, leisure and the ensuing after tax household income. Because the total time allocation is fixed (it cannot exceed 24 hours a day), we can write utility as a function $V$ of only five arguments, taking market work as the residual category (see time constraint below):

$$
V=V\left(t_{m}^{l}, t_{m}^{h}, t_{f}^{l}, t_{f}^{h}, y\right)
$$

\footnotetext{
${ }^{3}$ A discrete choice model of labour supply has also been used by, for example, Aaberge et al. $(1995,1999)$, Hoynes (1996), and Keane and Moffitt (1998). See also Dagsvik (1994) on the theoretical foundation of the usual functional form assumptions in this type of model.
} 
The budget constraint (2) gives family income $y$ after taxes and benefits as a function of gross earnings, total household non-labour income $Y_{0}$, and the amount of taxes and benefits $T{ }^{4}$ which depends on the various income components and on household characteristics $X$ :

$$
y=w_{m} t_{m}^{w}+w_{f} t_{f}^{w}+Y_{0}-T\left(Y_{0}, w_{m} t_{m}^{w}, w_{f} t_{f}^{w}, X\right)-\mathbf{1}\left\{t_{m}^{w}>0\right\} F C_{m}-\mathbf{1}\left\{t_{f}^{w}>0\right\} F C_{f}
$$

Partners' gross wage rates are denoted by $w_{m}$ and $w_{f}$. The final two terms reflect the fixed costs of market work of each partner (where $\mathbf{1}\{$.$\} denotes the indicator function as standard).$ The household also faces two time constraints given by the total hours endowment $E$ (say 24 hours per day) for each partner:

$$
\begin{aligned}
& t_{m}^{l}=E-t_{m}^{w}-t_{m}^{h} \\
& t_{f}^{l}=E-t_{f}^{w}-t_{f}^{h}
\end{aligned}
$$

Therefore, household production is not modelled explicitly as for example in Apps and Rees (1999), but is incorporated implicitly by allowing the partners' paid and unpaid housework to enter the model through $t_{m}^{h}$ and $t_{f}^{h}$. Here the marginal utilities capture not only how partners value paid work relative to housework, but also the utility that comes from household production (which increases with $t_{m}^{h}$ and $t_{f}^{h}$ ). ${ }^{5}$ In particular, the implications of the model as given by the expected signs of the partial derivatives of $V$ are as follows:

- $\frac{\partial V}{\partial t_{m}^{l}}>0$ if husband's leisure is preferred to husband's paid work, keeping constant the other arguments of $V$ (including husband's housework and after tax family income $y$ ).

- $\frac{\partial V}{\partial t_{f}^{l}}>0$ if leisure of the wife is preferred to paid work of the wife, keeping other factors constant.

\footnotetext{
${ }^{4} T$ also captures welfare transfers (see Section 3), which can be seen as negative tax payments.

${ }^{5}$ The model does not specify private consumption (this is not observed in the data either), which implies that we cannot analyze the consequences of policy changes that affect the prices of goods or services bought from the market (such as a change in VAT) and that may substitute for home produced goods or services (not subject to VAT, as it is hard to measure the output of home production).
} 
- $\frac{\partial V}{\partial t_{m}^{h}}>0$ if housework done by the husband is preferred to paid work done by the husband, keeping other arguments of $V$ constant, including $t_{m}^{l}$ and $y$. If paid and unpaid work hours are equally attractive or unattractive, we expect $\frac{\partial V}{\partial t_{m}^{h}}>0$ because housework increases household production, while income from paid work $(y)$ is kept constant.

- $\frac{\partial V}{\partial t_{f}^{h}}>0$ if housework done by the wife is preferred to paid work done by the wife, keeping the other arguments of $V$ constant.

- $\frac{\partial V}{\partial y}>0$ if more household income is better, keeping the allocation of hours chosen by the couple (and therefore also the household production) constant.

As in Van Soest (1995), only the final inequality is needed to ensure that the model is consistent with the underlying theory as it excludes the possibility that utility falls with income -we assume that the household chooses a point on its budget frontier. There is no need to impose any restrictions on the second order derivatives of $V$, such as quasi-concavity because to estimate the model we do not have to recur to first and second derivatives -we simply need to compare a finite number of utility values. Finally, the model is static and we do not account for savings (see Blundell and Walker, 1986, for a two-stage budgeting approach).

\section{Empirical specification}

To implement the model empirically, we allow partners to choose their time allocation as follows. We consider 7 discrete possible choices for each activity and for each spouse, which results in a discrete choice set for the household of $7 * 7 * 7 * 7=2,401$ possible choices. 
For each combination of paid and unpaid work hours of the two partners ${ }^{6}$ and for given gross wage rates and household non-labour income, we calculated income taxes and welfare transfers (see Section 3) and therefore, after tax income for each point in the choice set. We assume that partners can choose any combination of hours and ignore possible demand side restrictions (see, for example, Aaberge et al., 1999, for an extensive and more complete approach to this issue). However, our baseline model does incorporate fixed costs of paid work which may partly account for some of these rigidities (and see also robustness checks in Section 5). ${ }^{7}$ We use a flexible quadratic objective function: ${ }^{8}$

$$
V(\mu)=\mu^{\prime} A \mu+b^{\prime} \mu ; \mu=\left(t_{m}^{l}, t_{m}^{h}, t_{f}^{l}, t_{f}^{h}, y\right)^{\prime},
$$

where $A$ is a symmetric $5 * 5$ matrix of unknown parameters with entries $\alpha_{i j}(i, j=1, \ldots, 5)$, and $b=\left(b_{1}, \ldots, b_{5}\right)^{\prime}$ is a five-dimensional vector. We assume that $b_{1}, \ldots, b_{4}$ are functions of a vector $x$ of observed household characteristics (such as partners' ages, and the numbers of children in several age groups) and of unobserved characteristics using the following specification: ${ }^{9}$

$$
b_{j}=\sum_{k} \beta_{k j} x_{k}+\xi_{j} ; \quad j=1,2,3,4
$$

Here the four unobserved heterogeneity components $\xi_{j}(j=1,2,3,4)$ are assumed to be normally distributed with mean zero and arbitrary covariance matrix, independent of the $x_{k}$ and of other exogenous components of the model, such as the household's non-labour income and the determinants of gross wage rates. To keep the numerical optimization of the likelihood practically feasible, we do not parameterize $\alpha_{i j}(i, j=1, \ldots, 5)$ or $b_{5}$, but assume they

\footnotetext{
${ }^{6}$ For paid work of men and women, the choices are $0,1.6,3.2,4.8,6.4,8$ and 9.6 hours per weekday. For housework, we use slightly different choices for the two partners (because of the large differences in the observed sample distributions of housework hours of partners, see Section 3). We specify 0. 1, 2, 3, 4, 5 and 6 hours per weekday for men, and 1, 2.5, 3.5, 4.5, 5.75, 7.5 and 9.5 hours per weekday for women.

${ }^{7}$ It may also be argued that each household needs to do a certain amount of housework, particularly if there are children.

${ }^{8}$ To simplify the computational burden, the coefficient of income squared is set to zero, following, for example, Van Soest et al. (2002).

${ }^{9}$ The index of the household is suppressed.
} 
are the same for all households. ${ }^{10}$ Fixed costs of paid work are not observed but are modelled as two unknown parameters to be estimated (one for each partner).

Random error terms are added to the utilities of all $m=2,401$ points in the household's choice set as in Van Soest (1995):

$$
\begin{aligned}
& V_{j}=V\left(t_{m j}^{l}, t_{f j}^{l}, t_{m j}^{h}, t_{f j}^{h}, y_{j}\right)+\varepsilon_{j} \quad j=1,2, \ldots, m ; \\
& \varepsilon_{j} \sim \operatorname{GEV}(\mathrm{I}) ; \quad j=1,2, \ldots, m ; \\
& \varepsilon_{1}, \varepsilon_{2}, \ldots . ., \varepsilon_{m} \text { independent of each other and of everything else }
\end{aligned}
$$

GEV(I) denotes the type I extreme value distribution with cumulative density $\operatorname{Pr}\left(\varepsilon_{j}>z\right)=\exp (-\exp (-z))$. It is assumed that each household chooses the option $j$ that maximizes $V_{j}$. Our specification of the error terms implies that the conditional probability that a given combination $j$ is chosen (given observed and unobserved individual characteristics, wage rates, other household income, and income taxes), is the following (multinomial logit type) probability: ${ }^{11}$

$$
\operatorname{Pr}\left(V_{j}>V_{k} \text { for all } \mathrm{k} \neq \mathrm{j} \mid \ldots\right)=\exp \left(V\left(t_{m j}^{l}, t_{f j}^{l}, t_{m j}^{h}, t_{f j}^{h}, y_{j}\right)\right) / \sum_{k=1}^{m} \exp \left(V\left(t_{m k}^{l}, t_{f k}^{l}, t_{m k}^{h}, t_{f k}^{h}, y_{k}\right)\right)
$$

The scale of the utility function is thus fixed by the magnitude of the common variance of the error terms $\varepsilon_{j}$. The errors can be interpreted as unobserved utility components that make specific combinations of hours in the choice set more attractive than others (in line with the random utility concept in the standard multinomial logit model), or as optimization errors (e.g., errors in the household's perception of the alternatives' utilities).

The probabilities in (7) depend upon the values of the unobserved heterogeneity terms. In order to construct the likelihood contribution of a given household, these terms need to be integrated out. The likelihood contribution then becomes:

\footnotetext{
${ }^{10}$ As usual, the utility function is identified up to a monotonic transformation only. This would make it hard to identify the parameters in a more general model.

${ }^{11}$ For partners that report to be employed but do not report (regular) working hours, the likelihood contribution is set equal to the sum of all the probabilities of reporting positive hours choices.
} 


$$
\operatorname{Pr}\left[\left(t_{m}^{l}, t_{f}^{l}, t_{m}^{h}, t_{f}^{h}\right)=\left(t_{m j}^{l}, t_{f j}^{l}, t_{m j}^{h}, t_{f j}^{h}\right)\right]=\int_{-\infty}^{\infty} \int_{-\infty}^{\infty} \int_{-\infty}^{\infty} \int_{-\infty}^{\infty} \operatorname{Pr}\left(V_{j}>V_{k} \text { for all } \mathrm{k} \neq \mathrm{j} \mid \xi, \ldots .\right) p(\xi) d \xi
$$

Here $p(\xi)$ is the density of the vector $\xi$ of unobserved heterogeneity terms. ${ }^{12}$ The likelihood expression involves four-dimensional integrals, which are approximated using simulated maximum likelihood (see Train, 2003). ${ }^{13}$

The likelihood contribution in equation (8) assumes that gross wage rates are observed and exogenous. Therefore, we estimated Heckman selection type of model of partner's gross wages (separately for men and women) to be able to predict wages for non-participants (as well as for individuals that did not report wages; see Section 4 for more details). We replaced observed wages with predicted wages for everyone in the sample and, alternatively, we tested for the sensitivity of the estimates to using observed wage rates whenever available. ${ }^{14}$

\section{Income taxes and benefits}

Married spouses are subject to joint taxation of their incomes (that are are added up for income tax purposes) in France. This typically leads to a lower tax rate for the primary earner (usually the husband) and viceversa, a larger tax rate for the secondary earner (often the wife) than under separate income taxation. It follows that joint taxation of spouses' incomes may create disincentives to work longer for secondary earners while possibly making housework more attractive (as an extra hour of market work is taxed at a higher tax rate than under independent taxation while housework is not taxed) . Most OECD countries have moved to a system of individual taxation or allow couples to choose between the two systems. In contrast to married spouses, cohabiting partners' incomes were taxed separately in France at the time

\footnotetext{
${ }^{12}$ The notation here does not make the conditioning on observed variables explicit, for simplicity.

${ }^{13}$ We used 100 Halton draws for each household and each unobserved heterogeneity term.

${ }^{14}$ The difference between the results of estimation under these two alternative approaches can also be seen as a robustness check. Ideally, the wage equations should be estimated jointly with the structural model, which would, however, substantially increase the computational burden.
} 
of our survey data. ${ }^{15}$ Here we model the income tax system for both married and cohabiting partners.

A key feature of the French income tax scheme is the "family quotient" ("quotient familial" ), say $q$. The family quotient gives weight one to each married spouse, weight 0.5 to the first and second child, and weight one to children of birth order higher than two. Total (household) taxable income is divided by $q$ before applying the tax brackets (see Figure 1), and then the resulting amount is multiplied by $q$ to give the income tax payable by the household. Thus, for a married couple with two children, total taxable income of the two spouses is divided by $q=1+1+0.5+0.5=3$ before applying the tax brackets, and the resulting amount is multiplied by 3 to give the total income tax payable by the household. In contrast, for an unmarried couple with two children, the two partners file income taxes separately, and thus must choose how to report children for income tax purposes. If each of them reports one child, the family quotient for each of them will be $q=1+0.5=1.5$. Combined with the progressive income tax brackets, this system implies that keeping household income constant, the tax paid by a married couple may well be lower than that paid by a cohabiting couple. In particular, a married couple in which only one spouse works and earns, say, $\mathrm{y}^{*}$ will pay as much income tax as a married couple in which both spouses work and together earn $\mathrm{y}^{*}$ (and less income tax than a cohabiting couple in which only one spouse works and earns $\left.y^{*}\right)$. It follows that this system may discourage participation of married secondary earners (see, for example, Apps and Rees, 2011, or Stancanelli, 2008).

The 1998 French income tax brackets that applied to total taxable household income are illustrated in Figure 1. There were six income brackets with marginal rates increasing from zero to 54\%. The base is gross household income (net of payroll taxes or social security contributions). To calculate the household income tax payable, the following steps are taken:

\footnotetext{
${ }^{15}$ Only since the introduction of the "Pacte Civil de Solidarite et de concubinage (pacs)" in 1999, unmarried couples can file jointly, after an initial waiting time of three years. Thus, they could not file jointly before 2002 .
} 
1. Standard deductions (on average $28 \%$ of total household income ${ }^{16}$ ) are subtracted from total household income to give 'taxable' household income.

2. Taxable income $Y$ is divided by the family quotient, $q$, which gives the taxable income ratio $\mathrm{Y}^{\prime}$.

3. The tax rates shown in Figure 1 are applied to $\mathrm{Y}^{\prime}$ producing $\mathrm{T}$ '.

4. The amount $\mathrm{T}^{\prime}$ is multiplied by $q$ and this gives the income tax payable, $\mathrm{T}$.

5. Low-income households benefit from an additional income tax reduction according to a formula ("la decote") that depends on the income tax payable (T) itself. ${ }^{17}$

According to administrative sources ${ }^{18}$ the average (effective) income tax rate for married couples aged less than 60 - the same age cut-off that we use in our sample - is 5.34\%, much lower than in most OECD countries, and more than $25 \%$ did not pay any income taxes. This is in line with our calculations. For example, a married couple with two children and total annual income of $€ 60,000$ has an effective tax rate of approximately $8 \%$, which is low by international standards. Let us note again that unlike in other countries, these income tax rates do not include social security premiums, which are very large in France ${ }^{19}$, and a considerable part of government revenue in France is raised by means of value added tax ${ }^{20}$ (that is, regressive taxation) which we do not model here.

Figures 2 and 3 show the average tax rate for the household (calculated as the amount of total household tax payable, divided by the total income of both partners) as a function of

\footnotetext{
${ }^{16}$ Following a similar approach as, for example, Bourguignon and Magnac (1990).

${ }^{17}$ If the total income tax payable $(T)$, was less than $€ 508$, it was reduced to max $(0,2 T-508)$. Low-income cohabiting partners could both benefit from this tax reduction.

${ }^{18}$ Enquête Revenus Fiscaux, drawn from administrative income tax files, INSEE, Paris, 1998.

${ }^{19}$ Besides, the survey collects information on wages net of social security contributions and gross of income taxes. Thus, we do not observe social security contributions and we do not model them either. Social security contributions are levied on both employers and employees and their design is extremely complicated.

${ }^{20}$ The amount of revenue levied by means of value added taxes is equal to about 7 per cent of GDP against 10.3 of GDP for income tax revenue

(http://epp.eurostat.ec.europa.eu/statistics_explained/index.php/Tax_revenue_statistics). Goods produced within the household such as home cooked meals are not subject to value added tax since the output of household production is hard to measure. In contrast, private goods bought from the market are subject to value added tax.
} 
her annual earnings, and holding fixed his annual earnings. For married couples, the tax rate on each additional euro depends on the earnings of both spouses. For cohabiting couples, who are subject to individual taxation, the tax rate on her earnings is independent of his earnings. As a consequence, cohabiting women pay no income tax if their earnings are very low. The average household tax rate as a function of her earnings (which is depicted in Figures 2 and 3 ), is higher at lower earnings of the female partner in (childless) cohabiting couples than in (childless) married couples (see panels 2, 3 and 4 in Figures 2), simply because in married couples the couple's earnings are divided by two $(\mathrm{q}=2)$ before applying the tax schedule (see discussion above). If the couple has children, cohabiting partners can choose who reports them in order to minimize their income tax burden (see also Figure 3), and this is the assumption we make in our model, in which we assume that cohabiting couples report their children for tax file purposes so as to minimize the total tax burden. It follows that for various combinations of partners' earnings and family composition, the couple may pay a different income tax for similar total household level depending on marital status (which we take as given here).

Finally, our model does not account for unemployment benefits (which are temporary and depend upon labour market history and involuntary job loss), but we do incorporate social assistance benefits, in line with the literature on static discrete choice labour supply models (see, for example, Van Soest, 1995). Social assistance benefits are means tested (conditional) on total household income for both married and cohabiting couples and increase with the number of children. We do not explicitly incorporate the costs of child care but control for the presence and ages of children in the model as well as including fixed costs of work for both partners. ${ }^{21}$

\footnotetext{
${ }^{21}$ Child care costs of children younger than three vary with the form of childcare used by the household but are all tax deductible. Children of age three to six are enrolled in maternal school, which is open ten hours a day and free of charge (a symbolic fee is paid for meals, proportional to household income) and almost 100\% of French children in this age range are enrolled into maternal school. Older children are enrolled in elementary school
} 


\section{The data}

The data for the analysis are drawn from the 1998-99 French Time Use Survey, carried out by the National Statistical offices (INSEE). This survey is a representative sample of more than 8,000 French households with over 20,000 individuals of all ages. Selecting couples, married or cohabiting but living together, gave a sample of 5,287 couples with and without children. The response rate to the survey was $80 \%$ for couples (see also, for example, Lesnard, 2009). We selected couples in which both partners were younger than 60 - the legal minimum retirement age for most workers in France in 1998-99 - and neither spouse was in full-time education, in the military, on disability benefits, or in early retirement. ${ }^{22}$ We kept self-employed individuals in the sample (whose hours, earnings and total household income were reported in the same way as for employees).

Three questionnaires were collected: a household and an individual questionnaire, and a time use diary. The diary was filled in by all household members on the same day, and this day was chosen by the interviewer. About two thirds of the sample filled in the time diary on a week day, and less than a third on a weekend day. We dropped all households who filled in the diary on a weekend day (on which housework is typically not constrained by hours of paid work $^{23}$ ) or on an atypical day (like a vacation day, a day of a wedding or a funeral, or a sick leave day), as well as households in which either partner did not fill in the diary. Dropping observations of households who were chosen to complete their time use diaries at the weekend implies that our results refer to partners' time use on week days only. Our final sample for analysis contains 2,141 couples. Table 1 shows how many households are deleted from the sample in each of the selection steps described above.

\section{Sample descriptives, wages and income variables}

which is also open ten hours a day and free of charge (a symbolic fee is paid for meals, proportional to household income).

${ }^{22}$ We kept housewives as well as men who report that housework is their main occupation (less than ten cases).

${ }^{23}$ Very few individuals reported any paid work at weekends. 
Tables 2 and 3 present descriptive statistics. The average number of dependent children younger than 18 years in the household was slightly over one, implying that $39 \%$ of couples in the sample had no children. Only $6 \%$ of the sample were not French nationals. Approximately 18\% lived in the region of Paris ("Ile-de-France"). Married couples represented $79 \%$ of the sample while the remaining $21 \%$ were cohabiting. Hourly earnings were computed for respondents who reported continuous (monthly) earnings information, dividing (gross of income tax and net of social security contributions) earnings by usual hours of paid work. The observed average gross wage rates were $€ 9.83$ per hour for men and $€ 8.24$ for women. About $94 \%$ of the men and $70 \%$ of the women were engaged in gainful employment at the time of the survey. About $20 \%$ of men and women were self-employed. Average usual hours worked per week were roughly 29 for men and 19 for women, including the zeros for non-workers. Moreover, 360 men and 240 women did not report usual hours, but did report that they were involved in gainful employment. In this case we know that their usual hours are positive and thus, account for this when specifying their likelihood contribution (see Section 2 for details).

We predicted wage rates for non-participants as well as for those that did not report wages by estimating a Heckman selection model for men and women separately (see Appendix A). In particular, surveyed individuals were given the choice to either report in which broad interval their earnings fell or to report the exact monthly earnings. We only use information on exact (continuous) wages in the Heckman model. These reported measures of earnings are all (gross) before income tax but net of social security premiums. ${ }^{24}$ Moreover, to predict gross (before income tax) hourly wages we use a larger sample than the one used to estimate the model, as we also include singles as well as individuals that answered the diary

\footnotetext{
${ }^{24}$ Wage rates below half the legal minimum were set to missing (since in some jobs like for example full-time baby-sitting and other special employment contracts, it is legal to pay as low as half the minimum wage per hour). Wage rate predictions were never below the minimum wage. The Heckman selection equations were estimated using a larger sample that included also weekend diaries.
} 
on a weekend day or an exceptional day. The presence and age of children and the presence of other adults in the household were used to identify the male selection equation from the wage equation. To identify the female selection equation we additionally used marital status dummies, as marital status turned out not to affect female (hourly) wage rates ${ }^{25}$ and, therefore, these exclusion restrictions we statistically significant. The selection term is large and significantly positive for women, implying that women with unobserved characteristics that make them more productive have a larger participation probability. The exclusion restrictions are not significant for the male participation equation, except for the presence of children aged less than three years, which is significant at the ten per cent level (see Appendix A), and the selection term for male participation is not statistically significant. This is not surprising as most men would like to work for pay in the market as commonly found in earlier literature. Next, we conclude that potential experience and education affect significantly wage rates of both men and women -and this may also help identify predicted wages in the discrete choice model. Ideally one would like to estimate wages simultaneously with the discrete choice model (see Section 2). The lack of exogenous source of variation in wages is a drawback of using such a cross-sectional dataset, which on the other hand is one of the rare surveys to provide detailed information on both partners' time allocation and income. We test for the sensitivity of the results of estimation of the model to using observed wages for individuals that reported continuous wages or replacing wages with predicted wages for everyone in the sample (see next section).

More than $25 \%$ of the sample reported zero non-labour household income (see Table 3). Non-labour household income represents approximately $25 \%$ of total household income

\footnotetext{
${ }^{25}$ This is in line with earlier literature that suggests that employers expect all women to marry at some stage and thus apply the same wage 'penalty' to all women, regardless of marital status. Indeed, we found significant wage premiums for married men but not for married women.
} 
before taxes. ${ }^{26}$ The average effective tax rate (the ratio of total household income tax and total household before tax income) is approximately $5.6 \%$ of total household (before tax) income, which is well in line with the administrative data (see also Table 1 and Section 3). The average effective income tax rate is lower for married couples (5.5\% on average) than for cohabiting couples $(6.1 \%)$.

\section{Time allocation}

The diary was filled in by each partner on the same week day, which was chosen by the interviewer, spanning 24 hours. Activities were coded in ten minutes slots and approximately 140 possible activities were distinguished by the survey coders. Here, we distinguish the following 'primary ${ }^{27}$ activities:

1. Paid work, carried out either at home or at an outside work place.

2. Housework, defined to include cleaning, shopping, cooking, doing the laundry, setting and unsetting the table, doing the dishes, doing administrative work for the household as well as any (primary) time spent caring for children.

3. "Leisure" time, defined as any time devoted to leisure (watching television, doing sports, socializing and recreational activities), 'semi-leisure activities' (such as gardening or taking care of pets), as well as personal care and sleeping time.

The distribution of partners' time allocations is illustrated in Table 4, which shows that men do the bulk of paid work: the median "husband" in the sample spends approximately 480 minutes ( 8 hours) on market work, compared to 240 minutes (4 hours) for the median "wife" -denoting the male partner as the 'husband' and the female partner as the 'wife', for simplicity, as we have included cohabiting couples in the sample. In contrast, women

\footnotetext{
${ }^{26}$ This is before accounting for welfare benefits that are included in our simulation model (see Section 3 for details).

${ }^{27}$ Respondents were also asked to fill in "secondary" activities which are activities carried out simultaneously, such as cooking while taking care of children. The respondent may report childcare as primary activity and cooking as secondary activity or vice versa. Generally, ignoring secondary activities is likely to underestimate the amount of unpaid work. However, very few respondents in the sample reported some secondary activities, and thus, we resolved to ignore secondary activities. Moreover, if we counted in also time spent on secondary activities, the time budget would not satisfy the 24 hours constraint any longer.
} 
perform most of the housework: with the median "wife" doing 240 minutes of housework against 30 minutes for the median "husband". ${ }^{28}$ Interestingly, a comparison of total paid and unpaid work time of partners shows that the median "wife" works 10 minutes more than the median "husband" (see also Burda et al., 2013, on total work load by gender). In the empirical analysis, the time spent on paid work and housework, respectively, by each partner, is rounded to the nearest of the seven discrete point intervals in the choice set (see Section 2).

Finally, to better grasp within-couple differences in the division of paid and unpaid work, we present the share of the husband's time in the total time devoted by the couple to each activity (see Table 5). This shows that the husband provides on average $61 \%$ of the paid work done by the couple (and 67\% of the median). In contrast, the median husband performs only $12.5 \%$ of the couple's housework load. The husband performs on average $45 \%$ of the total market and non-market work carried out by the couple (and $47 \%$ if we consider the median). To sum up, the wife tends to perform a little more work than the husband (and we have ignored here multi-tasking which is disproportionately done by women, as shown, for example, by Sayer, 2007). Our model will focus on whether this division of time allocations is sensitive to changes in tax rates and other financial incentives.

${ }^{28}$ See also Frazis and Stewart (2012) for a discussion of the limitations of using distributional comparisons. 


\section{Results of estimation of the model and income tax simulations}

We have specified a discrete choice utility model that allows both partners to choose between various combinations of market and housework hours and household net income (see Section 2). We modelled income taxes and benefits for both married and cohabiting couples (see Section 3) and estimated the model using French cross-sectional data on partners' time allocation and income (see Section 4). Here we present the results of estimation of the model and illustrate partners' time allocation responses to changes in net wage rates or non-labour income as well as simulating an income tax reform that would tax the incomes of married spouses separately (and cohabiting partners jointly).

\section{Baseline model}

We have allowed the parameters of the utility function $\left(b_{1}, \ldots, b_{4}\right.$ in Section 2$)$ to vary with partners and household characteristics (see equation (5) in Section 2) such as age, marital status, the presence and the age of dependent children. The systematic part of the utility function therefore, contains interactions of leisure and unpaid housework with the covariates. The parameter estimates of the systematic part of the utility function are given in Table 6 . The first block of coefficients in Table 6 is hard to interpret due to the quadratic and interaction terms. Therefore, Table 8 presents the average marginal derivatives of the utility function with respect to its five arguments, as well as the fractions of sample observations for which the predicted marginal utility is negative.

We find that the objective function increases with the level of household income for each combination of partners' leisure and housework hours chosen by the couples in the sample -as required for our model to have any meaningful economic interpretation (see also Section 2). Moreover, we conclude that most couples in the sample will choose more leisure than paid work for a given level of household income and housework hours, as reasonable. Nevertheless, the marginal utility of leisure is negative for about 27 percent of the male 
partners and about 42 percent of the female partners -meaning that some would be willing to work for free if there were no fixed costs of work (the fixed costs of work prevent them from doing so, see Table 6). The marginal utility of housework is positive for $65.2 \%$ of the women and $69.1 \%$ of the men, which indicates that (keeping household income constant), housework is more attractive than paid work for them, possibly because of the implied household production output (which is not kept constant in the model, see Section 2).

Moreover, a positive coefficient on the interaction of, for example, her age and her leisure hours implies a positive effect of her age on her marginal utility of leisure and a negative effect of her age on her marginal utility of paid work hours, 'ceteris paribus'. A positive coefficient on one of the interactions with her (his) housework similarly implies a positive effect on the marginal utility of her (his) housework against her (his) paid work. For example, we conclude that being married reduces the marginal utility of his housework, suggesting that cohabiting men perform more housework than married men. A plausible explanation for this finding is that cohabiting couples are less traditional and have different norms concerning the roles of men and women in the family. As expected, children - and young children in particular - strongly and significantly increase the marginal utilities of both partners' housework, although the effect of children is smaller for him than for her.

Table 7 gives the estimates of the distribution of the four-dimensional vector of random effects $\xi$ in the marginal utilities of leisure and housework time of both partners (cf. Equation (5)). The top panel shows that all variances are significantly positive, although their magnitude varies, suggesting that there is more unobserved variation in the preferences for leisure (compared to paid work) than in the preferences for housework, which is well plausible. The bottom panel shows that all estimated correlations are significantly positive, implying, for example, that time use and preferences of both partners are positively correlated, which indicates positive assortative mating. 
To gather some measure of the goodness of fit of our model, we compare predicted and observed (actual) participation rates and mean hours of market work and housework (see Table 9 and Figure 4). Our model appears to fit better the distribution of (hours spent on) housework than that of market work. In particular, over-time work is under-predicted by the model. Incorporating fixed costs of work helps us to fit partners' participation rates in paid work- as the model without fixed costs of work (see robustness checks) under predicts nonparticipation while over-predicting small part-time jobs.

\section{Hours responses to changes in wages and non-labour income}

Next, we use the parameter estimates from the baseline model to simulate the sensitivity of partners' time allocation decisions to changes in the (own or the partner's) wage rate or changes in other household income. In each scenario, the discrete distribution (with 2,401 mass points) of the hours devoted by each partner to market work and housework is simulated for all the couples in the sample, accounting both for unobserved heterogeneity and the error terms of the model (see Section 2). In particular, we simulate upward changes in partner's net wage rates as well as an increase in net non-labour household income.

Simulating an upward change in the her net wage allows us to estimate her uncompensated own wage 'elasticities' of paid and unpaid work hours as well as her participation rates and his corresponding cross wage 'elasticities' of market and housework hours. ${ }^{29}$ The net wage 'elasticities' are computed by increasing the net reward for each additional hour of work by $1 \%$ and then, comparing the outcomes for these new budget sets with the outcomes of the benchmark simulation, as usual. Similarly, the net non-labour income 'elasticities' are computed by first computing each household's expected income in the benchmark scenario and then increasing non-labour income by $1 \%$ of this amount for all points in the choice set. To compute the standard errors we replicate each simulation using 500 draws of (the vector

\footnotetext{
${ }^{29}$ Simulating changes in before-income-tax (gross) wage rates instead of net wage rates gives similar elasticities (somewhat smaller in absolute magnitude).
} 
of) the estimated parameters from the model (which was first estimated by simulated maximum likelihood using 100 draws, see also Section 2).

We find that her own wage 'elasticity' of market work is 0.55 (see Table 10), which is somewhere in the range of earlier female elasticities found for France -it is larger than the estimate of, for example, Bargain et al. (2013) and smaller than some of the estimates reported in Blundell et al., 2013, and Bargain et al., 2013 (Appendix A.1). According to our estimates, his own net wage elasticity of market hours is equal to 0.20 , which is quite large relative to earlier studies for France. More than half of the estimated responses of the own labour supply to changes in the own wage rate are due to changes in the own participation rate -and this is true for both the male and the female partner in the couple (and also in line with the findings of Bargain et al. (2013)). ${ }^{30}$

The cross wage 'elasticities' of market hours are statistically significant and negative. They are smaller in absolute size than the own wage 'elasticity', though very sizeable and equal to -0.10 for his market hours (in response to a change in her wage rate) and -0.31 for her market hours (in response to a change in his wage rate). These estimates are larger than the corresponding cross-'elasticities' found by Bargain et al. (2013). According to our estimates, most of the his cross-'elasticity' is due to changes at the intensive margin while more than half of her cross-'elasticity' is due to changes at the extensive margin. Estimated non-labour income 'elasticities' of market hours are negative for both partners and equal, respectively, to -0.125 for the male partner, and -0.248 for the female partner. These last elasticities are mainly due to responses at the extensive margin ${ }^{31}$ and the standard errors indicate that they are quite precisely determined and statistically significant.

\footnotetext{
${ }^{30}$ Note that the participation changes are given in percentage points; for the wife (the husband), the elasticity of participation is about $1.42(1.05)$ times as large.

${ }^{31}$ Non-labour income elasticities are not comparable to those in Bargain et al. (2013) who only consider changes in capital income and find very small responses.
} 
The second panel of the table presents the 'elasticities' of both partners' housework to changes in both partners' wage rates and net household non-labour income. The female partner responds to an increase in her wage rate by reducing the time allocated to non-market work (the 'elasticity' is equal to -0.362). In absolute terms, following an upward change in the own wage, the reduction in her unpaid work is smaller than the increase of her market work, which implies a drop in her leisure hours. Only a small (but statistically significant) part of the reduction in her housework is compensated by more housework been performed by the male partner -the cross elasticity of his housework to a change in her wage rate is 0.117 . This implies that the amount of housework performed by the male partner varies only slightly in response to an increase in her wage rate(he spends on average 1.29 hours per weekday on housework according to our baseline estimates). The significantly positive (though small) effect of an increase in her wage rate on his non-market work is in line with earlier findings by Bloemen and Stancanelli (2013), who did not account for income taxation.

The estimated 'elasticity' of his housework hours to his own wage rate is negative (0.337 ) and larger in absolute value than the wage 'elasticity' of his paid work. However, because men perform more hours of paid than unpaid work, the overall effect is smaller in absolute terms for housework than for paid work and it follows that an increase in his wage rate leads to a reduction in his leisure hours. The cross-effect of his wage rate on her housework hours is only marginally significant and quite small (the estimated elasticity is 0.054). In particular, following an increase in his wage rate, his housework drops and hers increases -not enough though to compensate for the reduction in his housework hours, so that the total housework done by the couple falls. Thus, an increase of either his or her wage rate reduces the total housework done by the couple, and possibly leads to more outsourcing of household chores. ${ }^{32}$

\footnotetext{
${ }^{32}$ An analysis of outsourcing of housework is given in Stancanelli and Stratton (2013). It is outside the scope of the current paper.
} 
Finally, the non-labour income 'elasticity' of the housework done by the male partner is negative and large in absolute value. In contrast, her housework response to a change in non-labour income is virtually zero and insignificant. Thus, total housework falls if other income increases which may suggest perhaps more outsourcing of housework tasks or, possibly, more "multi-tasking" or "leaving housework undone" (see Sayer, 2007, for more insights into all these options).

\section{Simulations of income tax reforms}

Next we simulated the effects of changing the tax system from joint taxation to separate taxation of married spouses' incomes, and viceversa for cohabiting partners. The two groups are split for these simulations: cohabiting couple are not included in the simulation of the income tax change for married spouses (for obvious reasons, as nothing changes for them), and viceversa, married couples are not included in the simulations for cohabiting partners.

As anticipated (see Section 3), replacing joint with separate income taxation for married couples increases the wife's participation and hours of market work and reduces the husband's market hours: average hours of paid work fall by $0.75 \%$ for the husband and increase by $3.66 \%$ for the wife (see Table 11). In contrast, housework hours increase by $1.28 \%$ for the husband and drop by $2.01 \%$ for the wife. Thus, these results suggest that replacing joint taxation with separate taxation of married spouses' incomes would lead to a slightly more balanced distribution of market and non-market work between the spouses though according to our simulation only few partners would change their time allocation in response to the reform (less than ten per cent of the married couples in the sample).

Next, we considered cohabiting couples and simulated their time allocation responses to replacing separate with joint taxation of their incomes. As expected, we find opposite patterns than above (see Table 11): cohabiting women are found to reduce their labour supply 
and increase their housework hours while the opposite is true for cohabiting men. The size of the responses of married and cohabiting partners differ, though, and this may be explained by compositional effects -cohabiting couples are often younger and have fewer children on average than married couples.

\section{Robustness checks}

Various robustness checks were carried out (see Table 11). We tested the stability of our estimation results by using a new set of Halton draws to estimate the distribution of the random coefficients. Next, we checked the robustness of the estimates to using the observed wages for individuals that reported continuous wages and replaced wages with predicted wages only for observations with missing wage information -this alternative approach implicitly assumes that the errors of the wage equation are independent of the unobservables of the discrete choice model of partners' time allocation. Furthermore, we re-estimated the model without allowing for fixed costs of work. Alternatively, we modelled restrictions to the availability of part-time jobs, including and excluding fixed costs of work. Finally, we estimated a simplified version of the model without housework, letting partners choose between leisure and market hours, ignoring housework in the model.

Using a new set of Halton draws (see Column 3 of Table 12), some of the estimated elasticities are slightly different but the qualitative conclusions are not affected. Replacing wages with predicted wages only for partners whose wages were not observed and thus, using reported wages whenever available (see Column 4 of Table 12), the results of the simulations are generally comparable, at least in terms of the direction of the effects, to those of our main specification, except for the elasticity of his housework which becomes positive in response to an increase in his wage or a change in the tax system, from joint to separate taxation of the incomes of married partners -though the size of both these effects is virtually zero. A possible 
explanation for these counterintuitive results -which go in opposite direction to our main findings (see Column 2 of Table 12) - is that the errors of the wage equation are not independent of the unobservables of the model and thus, these new estimates are inconsistent. Assuming the absence of fixed costs of work (see Column 5 of Table 12), the results are not affected in terms of the direction of the effects but their size differs quite substantially, relative to our favourite specification. Moreover, this specification fits the date worse than our preferred model (see earlier working paper version of the paper that did not account for fixed costs of work). In contrast, simulating restrictions in the availability of part-time jobs (as in Aaberge et al. (1995)), including or excluding fixed costs of work, improves the fit of the model (results not shown). Under this scenario, the direction of the effects studies is the same as in our preferred specification but the size of the estimates varies sometime quite substantially (see Columns 6 and 7 of Table 12). However, this specification results in more frequent negative marginal utilities of leisure and housework (results not shown) than for our baseline specification, and it is unclear whether this framework would be reasonable to assume here, as while in other countries like, for example, Italy there is a reported lack of part-time jobs, we are not aware of similar issues for France. Therefore, we prefer to retain our main specification.

Finally, we assumed that partners only choose between various combinations of paidwork and leisure, ignoring housework (which is then taken as equivalent to leisure), as in most earlier discrete choice models of family labour supply (such as, for example, Callan et al. (2009)). This simplified model leads to estimated elasticities that have the same sign as those in our preferred model though the size of the effects varies somewhat (see column 7 of Table 11). 


\section{Conclusions}

We study the impact of income taxation on partners' hours of market work and domestic work in French couples. We consider both married couples whose incomes are still subject to joint income taxation in France and cohabiting couples that were taxed independently at the time of our survey data. The theoretical household taxation literature concludes that income taxation is likely to affect not only market labour supply but also housework. However, it is difficult to sign a priori the effect of income taxation on partners' housework. Income taxation is likely to affect labour supply and housework hours in opposite directions because, for instance, downward changes in the net rewards from work reduce the opportunity cost of housework, making market work less attractive than housework.

There is limited empirical evidence available of the effects of income taxation on housework. Our model extends earlier discrete choice models of family labour supply by modelling not only partners' market work but also partner's housework. The model accounts for participation as well as hours decisions. The use of a discrete choice specification enables us to incorporate non-linear taxes and welfare benefits in the household budget set. The choice set has 2,401 points for each couple in the sample, since we have allowed for seven discrete paid market-work intervals and seven discrete unpaid-work intervals, for each spouse. Using French time use data to estimate the model, we find that both partners' time allocation decisions are responsive to changes in wage rates, household non-labour income, and the income tax system. In particular, we simulate a change from joint taxation of the incomes of married spouses to separate taxation.

We find that partners' housework responds significantly to changes in the own and the partner's wage rate. The wage elasticities of partners' housework hours are generally smaller in absolute value than those of paid work. We also conclude that replacing joint taxation with separate taxation of married spouses' incomes would increase the wife's participation in paid 
work by $2.3 \%$-points and her average market hours would go up by $3.7 \%$, while her housework hours would drop by $2.0 \%$. The husband would partly compensate for the changes in the wife's time allocation by increasing his housework hours by $1.3 \%$ and reducing his market hours by $0.8 \%$. These effects, though statistically significant, represent only a small step towards balancing market and non-market work of the husband and the wife. Had we not allowed for housework in the model, we might conclude that the husband's leisure time increases while the wife's leisure time drops following the tax reform.

To sum up, we find significant though small responses of partners' hours of market work and housework to a change in the income tax system, from joint to separate taxation of married spouses' incomes. This may perhaps be due to the small effective income tax paid by French married couples on average. We have not allowed here for any effects of social security contributions or value added tax on consumption and assumed throughout this study that marital status is exogenous. Having some policy change at hand would enable one to better identify the causal relations at stake. Future studies should tackle these issues, as well as possibly model weekend hours (spillover) effects that were neglected here. 


\section{References}

Aaberge, R., J.K. Dagsvik and S. Strøm (1995), Labor supply responses and welfare effects of tax reforms, Scandinavian Journal of Economics, 97(4), 635-659.

Aaberge, R., U. Colombino and S. Strøm (1999), Labour supply in Italy: An empirical analysis of joint household decisions, with taxes and quantity constraints, Journal of Applied Econometrics, 14(4), 403-422.

Alesina, A., A. Ichino, L. Karabarbounis (2011), Gender based taxation and the division of family chores, American Economic Journal: Economic Policy, 32(2), 1-40.

Apps, P. F. and R. Rees (1988), Taxation and the household, Journal of Public Economics, 35(3), 155-169.

Apps, P. F. and R. Rees (1999), The taxation of trade within and between households, Journal of Public Economics, 73(2), 241-263.

Apps, P.F. and R. Rees (2011), Optimal taxation and tax reform in two-earner households, CESifo Economic Studies, 57(2), 283-304.

Bargain, O., K. Orsini and A. Peichl (2013), Comparing labor supply elasticities in Europe and the US: New Results, Journal of Human Resources, forthcoming. 
Bloemen, H.G. and E.G.F. Stancanelli (2013), Market hours, household work, child care, and wage rates of partners: an empirical analysis, Review of Economics of the Household, forthcoming.

Blundell, R., A. Bozio and G. Laroque (2013), Extensive and intensive margins of labour supply: Working hours in the US, UK and France, Fiscal Studies, 34(1), 1-29.

Blundell, R. and I. Walker (1986), A life-cycle consistent empirical model of family labour supply using cross-section data, Review of Economic Studies, 53(4), 539-558.

Bourguignon, F. and Magnac T. (1990), Labor supply and taxation in France, Journal of Human Resources, 25(3), 358-389.

Burda, M., D.S. Hamermesh and P. Weil (2013), Total work and gender: facts and possible explanations, Journal of Population Economics, 26(2), 507-530.

Callan, T., A. van Soest and J. Walsh (2009), Tax structure and female labour supply: Evidence from Ireland, Labour, 23(1), 1-35.

Dagsvik, J.K. (1994), Discrete and continuous choice, max-stable processes, and independence from irrelevant attributes, Econometrica, 62(5), 1179-1205.

Frazis, H. and Stewart, J. (2012), How to think about time-use data: What inferences can we make about long- and short-run time use from time diaries?, Annales d'Economie et Statistique, 105-106, 231-246. 
Gelber, A.M. and J.W. Mitchell (2012), Taxes and time allocation: Evidence from single women and men, Review of Economic Studies, 79(3), 863-897.

Hoynes, H.W. (1996), Welfare transfers in two-parent families: Labor supply and welfare participation under AFDC-UP, Econometrica, 64(2), 295-332.

Keane, M. and R. Moffitt (1998), A structural model of multiple welfare program participation and labor supply, International Economic Review, 39(3), 553-589.

Kleven, H.J., C.T. Kreiner and E. Saez (2010), The optimal income taxation of couples, Econometrica, 77(2): 537-560.

Lesnard Laurent (2009), “La famille désarticulée: les nouvelles contraintes de l'emploi du temps », Lien Sociale.

Leuthold, J.H. (1983), Home production and the tax system, Journal of Economic Psychology, 3(2), 145-157.

Rogerson, R. (2009), Market work, home work, and taxes: A cross-country analysis, Review of International Economics, 17(3), 588-601.

Sayer, L., (2007), More work for mothers? Trends and gender differences in multitasking, in T. van der Lippe and P. Peters (Eds.), Competing claims in work and family life. Cheltenham: Edward Elgar. 
Stancanelli, E.G.F. (2008), Evaluating the effect of the French Tax Credit on the employment rate of women, Journal of Public Economics, 92(10-11), 2036-2047.

Stancanelli, E.G.F. and L. Stratton (2013), Her time, his time, or the maid's time: An analysis of the demand for domestic work, Economica, forthcoming.

Steiner, V. and K. Wrohlich (2004), Household taxation, income splitting and labor supply incentives - a microsimulation study for Germany, CESifo Economic Studies, 50(3), 541-568.

Train, K. (2003), Discrete Choice Methods with Simulation, Cambridge: Cambridge University Press.

Van Soest, A. (1995), Structural models of family labor supply: A discrete choice approach, Journal of Human Resources, 30(1), 63-88.

Van Soest, A., M. Das and X. Gong (2002), A structural labour supply model with flexible preferences, Journal of Econometrics, 107(1-2), 345-374. 
Figure 1. Marginal income tax rates for France in 1998.

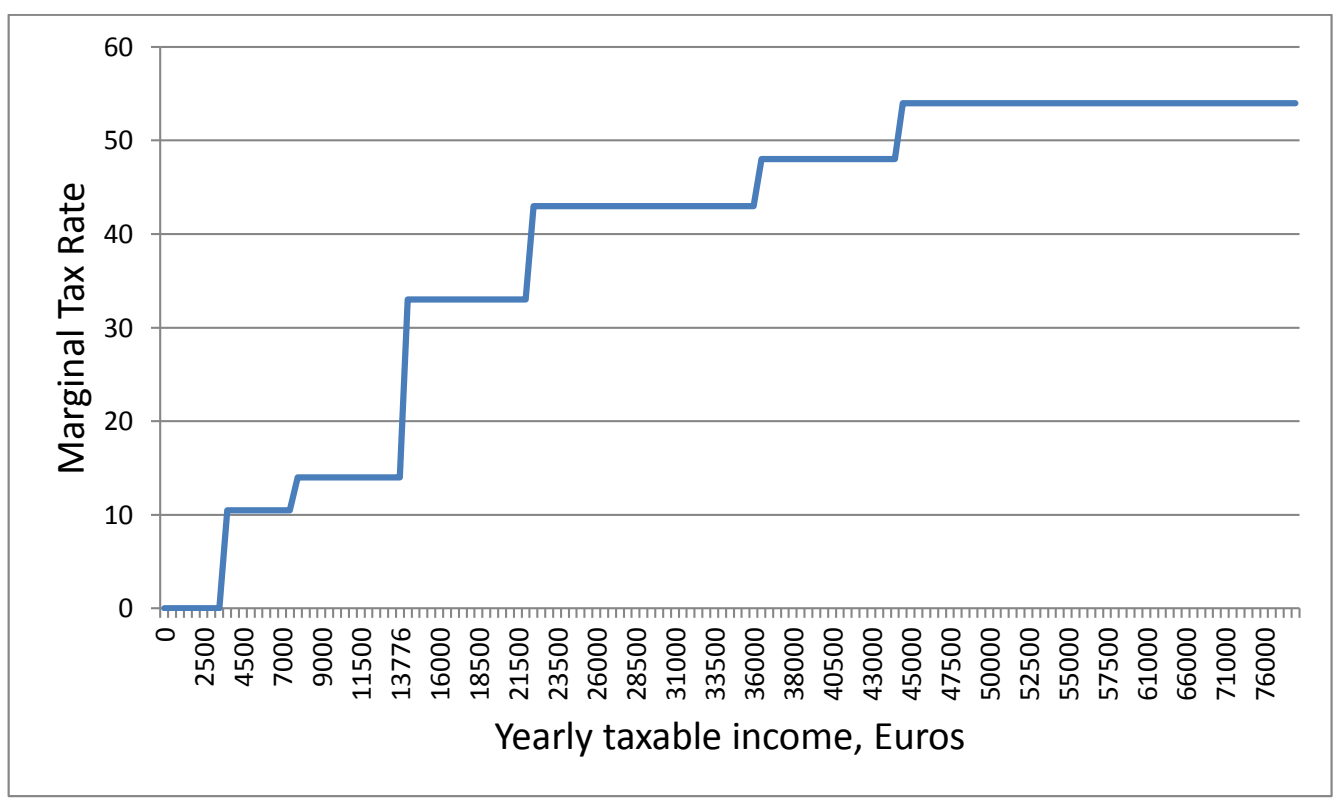


Figure 2. Average (effective) income tax rates for childless couples: the wife's earnings increase while the husband's earnings are fixed (at various thresholds).

\section{Childless Couples}
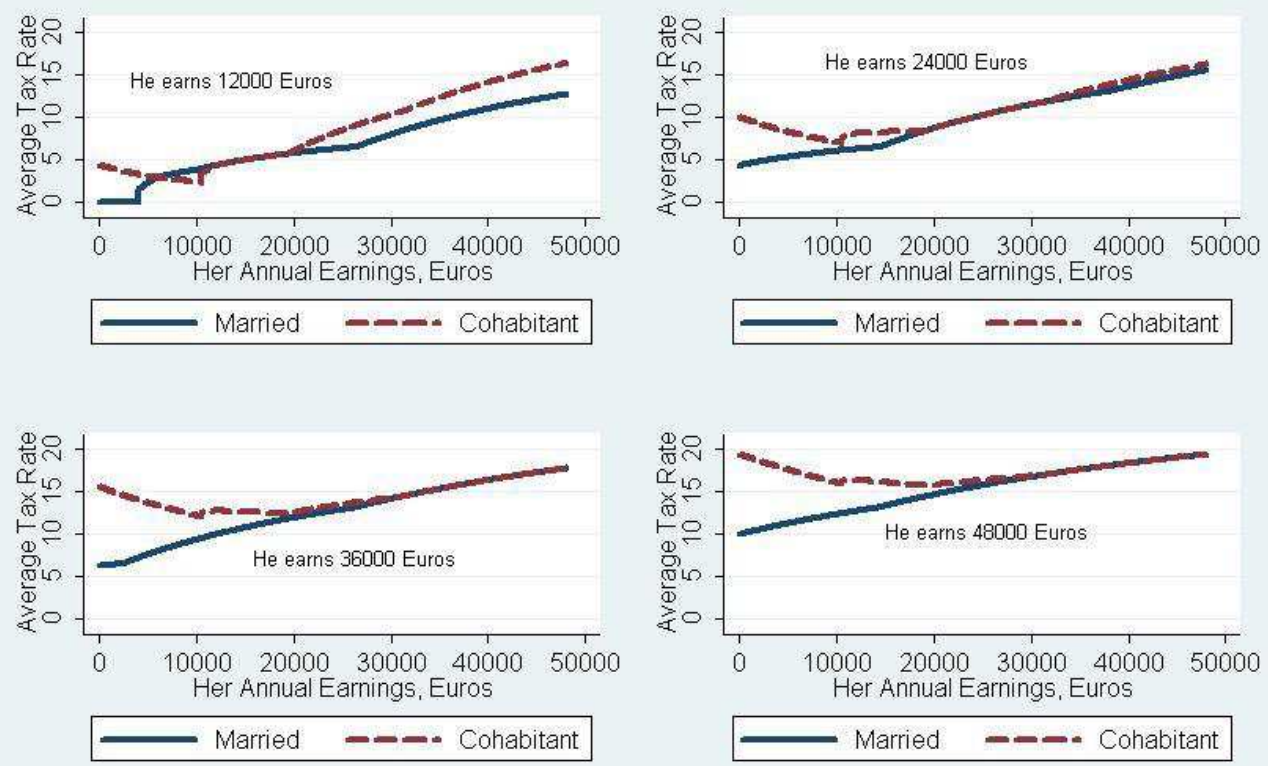

Note: Household Income tax as a proportion of Household Income. Her earnings increase from zero to 48000 
Figure 3. Average (effective) income tax rates for couples with two children: the wife's earnings increase while the husband's earnings are fixed (at various thresholds).

\section{Couples with Two Children}
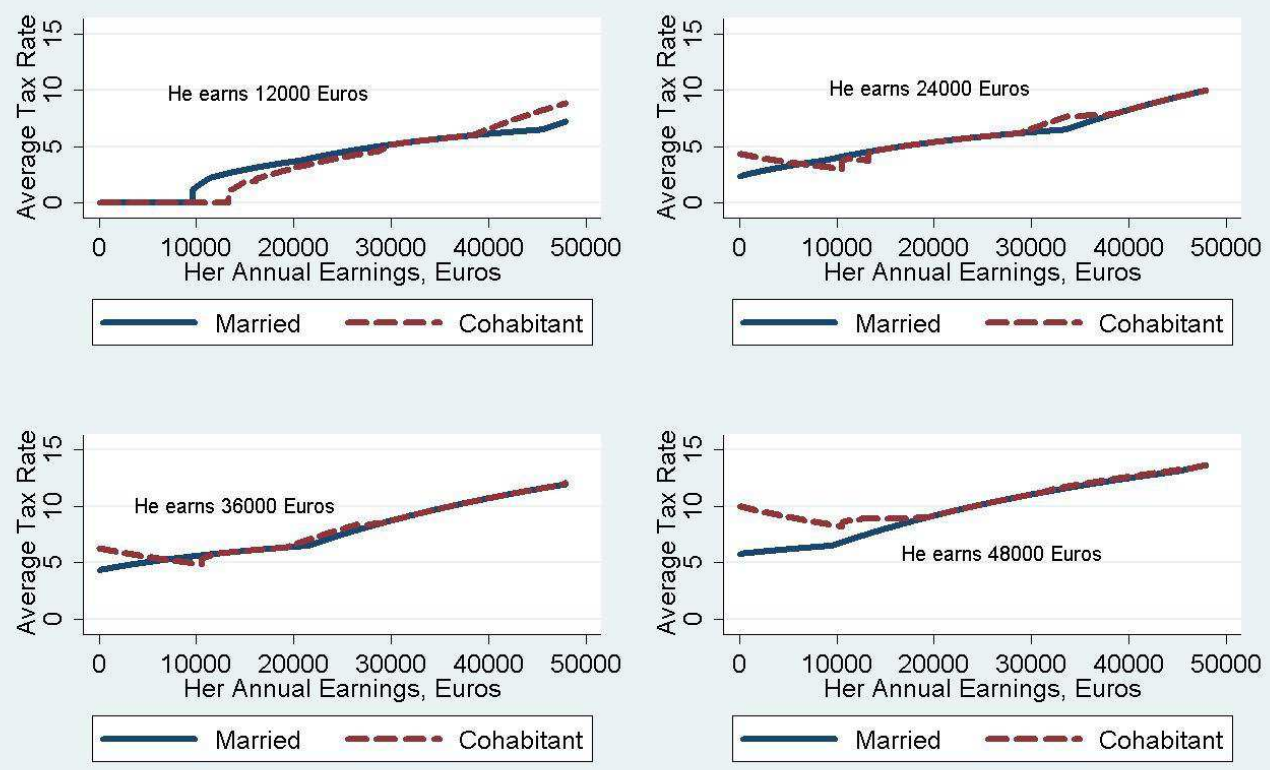

Note: Household Income tax as a proportion of Household Income. Her earnings increase from zero to 48000 
Figure 4. Predicted and Actual Hours Frequencies for the $(7 * 7 * 7 * 7)$ discrete choices Husband's Paid Work Husband's Housework
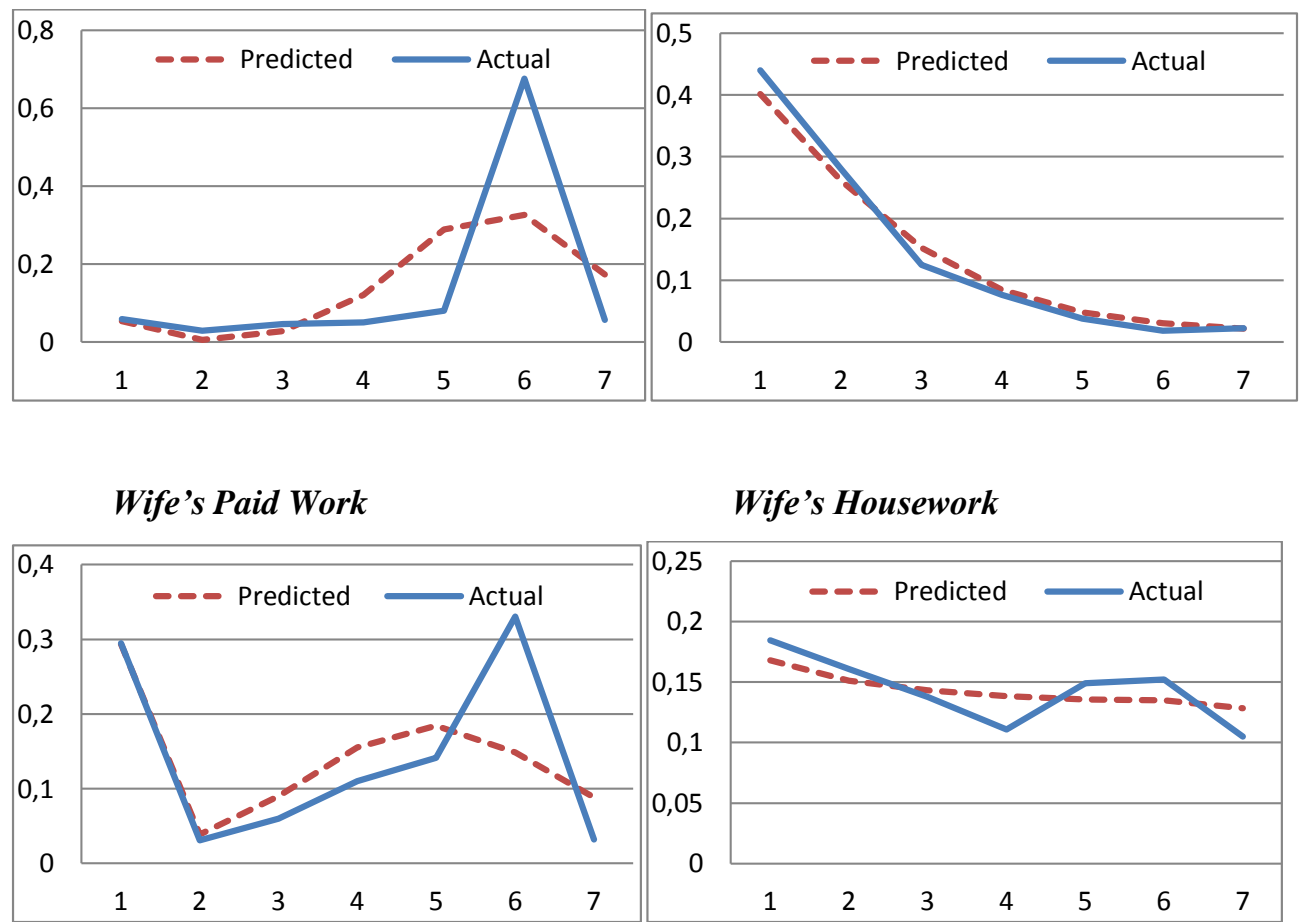
Table 1. Sample selection.

\begin{tabular}{lll}
\hline Selection Criterion & $\begin{array}{l}\text { Households } \\
\text { in the sample }\end{array}$ & $\begin{array}{l}\text { Households } \\
\text { dropped }\end{array}$ \\
\hline $\begin{array}{l}\text { Original sample size } \\
\text { Dropping single people }\end{array}$ & 5287 & \\
$\begin{array}{l}\text { Dropping couples with one or two partners } \\
\text { older than 59 years }\end{array}$ & 3819 & \\
$\begin{array}{l}\text { Keeping in households in which both } \\
\text { partners filled in the time diary }\end{array}$ & 3564 & 245 \\
$\begin{array}{l}\text { Dropping couples in which a partner filled in } \\
\text { the time diary on an atypical day }\end{array}$ & 3269 & 295 \\
$\begin{array}{l}\text { Dropping couples in which partners filled in } \\
\text { the time diary on Saturday or Sunday }\end{array}$ & 2407 & 862 \\
$\begin{array}{l}\text { Dropping couples with a partner in full-time } \\
\text { education or (early)-retirees or doing }\end{array}$ & & 266 \\
military service & 2141 & \\
\hline
\end{tabular}


Table 2. Descriptive Statistics.

\begin{tabular}{|c|c|c|c|c|}
\hline \multirow[b]{2}{*}{ Variables } & \multicolumn{2}{|c|}{ Husbands } & \multicolumn{2}{|c|}{ Wives } \\
\hline & Mean & St dev & Mean & St dev \\
\hline Age & 41.55 & 9.01 & 39.25 & 8.98 \\
\hline Elementary school & 0.08 & 0.28 & 0.10 & 0.30 \\
\hline Lower secondary, vocational & 0.06 & 0.24 & 0.10 & 0.30 \\
\hline Lower secondary & 0.37 & 0.48 & 0.28 & 0.45 \\
\hline Upper secondary vocational & 0.06 & 0.24 & 0.05 & 0.22 \\
\hline Upper secondary & 0.05 & 0.22 & 0.09 & 0.28 \\
\hline University short degree & 0.11 & 0.32 & 0.13 & 0.34 \\
\hline University degree or higher & 0.12 & 0.32 & 0.10 & 0.30 \\
\hline French nationality & 0.94 & 0.23 & 0.95 & 0.22 \\
\hline Employed & 0.94 & 0.32 & 0.70 & 0.47 \\
\hline Self-employed & 0.19 & 0.40 & 0.21 & 0.40 \\
\hline Ile-de-France (region of Paris) & 0.18 & 0.39 & & \\
\hline Regional unemployment rate & 11.28 & 2.35 & & \\
\hline Married & 0.79 & 0.41 & & \\
\hline Number of children $<18$ years & 1.10 & 1.12 & & \\
\hline Dummy child $<3$ years & 0.16 & 0.37 & & \\
\hline Dummy child 3-5 years & 0.15 & 0.36 & & \\
\hline Gross hourly wage predicted & 9.77 & 3.67 & 6.23 & 2.55 \\
\hline Gross hourly wage actual & 9.85 & 5.94 & 8.35 & 4.92 \\
\hline Usual paid work hours, weekly & 29.30 & 16.57 & 19.52 & 17.63 \\
\hline $\begin{array}{l}\text { Usual paid work hours, weekly } \\
\text { (excluding zeros) }\end{array}$ & 37.94 & 5.30 & 32.98 & 9.01 \\
\hline Paid work (diary), hours - daily & 6.97 & 3.76 & 4.02 & 3.93 \\
\hline Paid work, (diary) minutes - daily & 418.70 & 225.51 & 241.34 & 235.81 \\
\hline Housework, minutes & 65.27 & 85.45 & 272.49 & 169.26 \\
\hline Total work, minutes & 483.97 & 196.92 & 513.84 & 163.55 \\
\hline $\begin{array}{l}\text { "Leisure" (including sleep time and } \\
\text { personal care), minutes }\end{array}$ & 956.03 & 196.92 & 926.17 & 163.55 \\
\hline
\end{tabular}

The sample size is 2,141 couples. Hourly wages are gross of income taxes and net of social security contributions. Total work includes paid work and housework. For simplicity, we denote the male partner as the 'husband' and the female partner as the 'wife', regardless of marital status. 
Table 3. Descriptive Statistics: Income and Income Tax variables.

\begin{tabular}{lrrrr}
\hline & $Q 1(25 \%)$ & Q2 (Median) & Q3 (75\%) & Mean \\
\hline $\begin{array}{l}\text { Total earnings } \\
\text { (€ per year) }\end{array}$ & 12806 & 21953 & 32014 & 23876 \\
$\begin{array}{l}\text { Non-labour household } \\
\text { income }(€ \text { per year) }\end{array}$ & 0 & 1829 & 9513 & 7537 \\
$\begin{array}{l}\text { Total household income } \\
\text { before tax }(€ \text { per year) }\end{array}$ & 21953 & 28813 & 37137 & 31717 \\
$\begin{array}{l}\text { Total household income } \\
\text { after tax }(€ \text { per year) }\end{array}$ & 21108 & 26783 & 34426 & 29187 \\
Total tax burden $(€$ per year) & 0 & 987 & 3136 & 2416 \\
Effective tax rate $(\%)$ & 1.39 & 4.49 & 8.64 & 5.63 \\
\hline
\end{tabular}

Sample: 2,141 couples. The effective tax rate is defined as the tax amount paid divided by the total household income. The sample includes both married and unmarried couples. 
Table 4. Time Allocation of Partners (minutes per day).

\begin{tabular}{lrrrrr}
\hline & $10 \%$ & $Q 1$ & Median & $Q 3$ & $90 \%$ \\
\hline Husband paid work & 0 & 360 & 480 & 550 & 640 \\
Wife paid work & 0 & 0 & 240 & 480 & 520 \\
Husband housework & 0 & 0 & 30 & 100 & 180 \\
Wife housework & 70 & 140 & 240 & 390 & 510 \\
Husband "Total work" & 130 & 420 & 530 & 610 & 680 \\
Wife "Total work" & 280 & 410 & 540 & 630 & 700 \\
Husband "leisure" & 740 & 810 & 880 & 970 & 1170 \\
Wife Total "leisure" & 730 & 790 & 880 & 1000 & 1120 \\
\hline
\end{tabular}

Note: "Total work" time includes paid work and housework. Sample size: 2,141 couples; week day diaries. For simplicity, we denote the male partner as the 'husband' and the female partner as the 'wife', regardless of marital status, as the sample includes both married and cohabiting partners. 
Table 5. Husband's Share in Total Couple's Time

\begin{tabular}{llll} 
& \multicolumn{3}{c}{ Percentages } \\
& Mean & St deviation & Median \\
\hline Paid work & 66.88 & 30.96 & 61.07 \\
Housework & 19.82 & 22.69 & 12.50 \\
"Total work" & 46.76 & 15.38 & 48.78 \\
Leisure & 50.08 & 4.94 & 50.27
\end{tabular}

Notes: The shares are calculated only for couples in which at least one spouse spends a positive amount of time on the given activity. "Total Work" time includes paid work and housework (see Section 3 for definitions). For simplicity, we denote the male partner as the 'husband', regardless of marital status. 
Table 6. Estimation Results: Direct Utility functions

\begin{tabular}{|c|c|c|c|}
\hline Explanatory variables & Coefficient & Standard & error \\
\hline (Husband's leisure)^2 $^{\wedge}$ & -0.3057 & 0.0251 & $* *$ \\
\hline$($ Husband's housework)^2 & -0.263 & 0.0171 & $* *$ \\
\hline$(\text { Wife’s leisure })^{\wedge} 2$ & -0.2131 & 0.0147 & $* *$ \\
\hline$($ Wife’s housework)^2 & -0.0742 & 0.0111 & $* *$ \\
\hline Income*Husband's leisure & 0.0846 & 0.0089 & $* *$ \\
\hline Income*Husband's housework & 0.0276 & 0.005 & $* *$ \\
\hline Income*Wife's leisure & 0.0564 & 0.0061 & $* *$ \\
\hline Income*Wife's housework & 0.0278 & 0.0038 & $* *$ \\
\hline Husband's leisure* Husband's housework & -0.1468 & 0.0223 & $* *$ \\
\hline Husband's leisure* Wife's leisure & -0.0249 & 0.0068 & $* *$ \\
\hline Husband's leisure* Wife's housework & -0.0068 & 0.0085 & \\
\hline Wife's leisure* Husband's housework & -0.0157 & 0.0105 & \\
\hline Wife's leisure* Wife's housework & -0.0264 & 0.006 & $* *$ \\
\hline Wife's housework * Husband's housework & -0.0983 & 0.0118 & $* *$ \\
\hline Income & -2.1476 & 0.4353 & $* *$ \\
\hline Husband's leisure & 41.7887 & 7.663 & $* *$ \\
\hline Husband's leisure* log age & -17.3115 & 4.0494 & $* *$ \\
\hline Husband's leisure* log age^${ }^{\wedge}$ & 2.4329 & 0.5536 & $* *$ \\
\hline Husband's leisure* married & -0.2621 & 0.0829 & $* *$ \\
\hline Husband's leisure* number children & 0.0459 & 0.0368 & \\
\hline Husband's leisure* any child younger than 3 & -0.2048 & 0.1036 & $* *$ \\
\hline Husband's leisure* any child age 3-5 years & 0.0341 & 0.0969 & \\
\hline Husband's housework & 15.4829 & 5.6088 & $* *$ \\
\hline Husband's housework * log age & -5.5149 & 2.8852 & $*$ \\
\hline Husband's housework $* \log$ age ${ }^{\wedge} 2$ & 0.7975 & 0.3965 & $* *$ \\
\hline Husband's housework * married & -0.1988 & 0.0542 & $* *$ \\
\hline Husband's housework * number children & 0.114 & 0.0249 & $* *$ \\
\hline Husband's housework * any child younger than 3 & 0.1786 & 0.0668 & $* *$ \\
\hline Husband's housework * any child age 3-5 years & 0.0844 & 0.0626 & \\
\hline Wife's leisure & 52.8154 & 6.8603 & $* *$ \\
\hline Wife's leisure* log age & -25.0188 & 3.7753 & $* *$ \\
\hline Wife’s leisure* $\log$ age $^{\wedge} 2$ & 3.4764 & 0.5264 & $* *$ \\
\hline Wife's leisure* married & -0.2381 & 0.0763 & $* *$ \\
\hline Wife's leisure* number children & 0.1815 & 0.0378 & $* *$ \\
\hline Wife's leisure* any child younger than 3 & -0.1012 & 0.0876 & \\
\hline Wife's leisure* any child age 3-5 years & 0.1924 & 0.0865 & $* *$ \\
\hline Wife's housework & 24.4425 & 4.7226 & $* *$ \\
\hline Wife's housework $*$ log age & -11.8946 & 2.5555 & $* *$ \\
\hline Wife's housework $* \log$ age $\mathrm{e}^{\wedge} 2$ & 1.6968 & 0.3555 & $* *$ \\
\hline Wife's housework $*$ married & -0.0311 & 0.0489 & \\
\hline Wife's housework $*$ number children & 0.2376 & 0.0243 & $* *$ \\
\hline Wife's housework * any child younger than 3 & 0.2196 & 0.0536 & $* *$ \\
\hline Wife's housework * any child age $3-5$ years & 0.1558 & 0.0521 & $* *$ \\
\hline Husband's fixed costs of market work & -1.9277 & 0.1312 & $* *$ \\
\hline Wife's fixed costs of market work & -1.3231 & 0.0945 & $* *$ \\
\hline
\end{tabular}

**: significant at two-sided 5\% level; *: significant at two-sided 10\% level. For simplicity, we denote the male partner as the 'husband' and the female partner as the 'wife', regardless of marital status. 
Table 7. Estimation Results: Unobserved Heterogeneity

Covariance Matrix

\begin{tabular}{crrrr}
\hline & $\begin{array}{c}\text { Leisure } \\
\text { husband }\end{array}$ & $\begin{array}{c}\text { Housework } \\
\text { husband }\end{array}$ & Leisure wife & $\begin{array}{c}\text { Housework } \\
\text { wife }\end{array}$ \\
\hline Leisure & $1.4284^{* *}$ & & & \\
husband & $(0.1123)$ & & & \\
Housework & $0.3418^{* *}$ & $0.1353^{* *}$ & & \\
husband & $(0.0835)$ & $(0.0388)$ & & \\
Leisure wife & $0.7078^{* *}$ & $0.3169^{* *}$ & $0.7999^{* *}$ & \\
Housework & $(0.0656)$ & $(0.0506)$ & $(0.0649)$ & \\
wife & $0.3144^{* *}$ & $0.1788^{* *}$ & $0.4683 * *$ & $0.3051^{* *}$ \\
\hline
\end{tabular}

Correlation Matrix

\begin{tabular}{|c|c|c|c|c|}
\hline & $\begin{array}{l}\text { Leisure } \\
\text { husband }\end{array}$ & $\begin{array}{c}\text { Housework } \\
\text { husband }\end{array}$ & Leisure wife & $\begin{array}{c}\text { Housework } \\
\text { wife }\end{array}$ \\
\hline $\begin{array}{l}\text { Leisure } \\
\text { husband }\end{array}$ & $\begin{array}{r}1.0000 \\
(0.0000)\end{array}$ & & & \\
\hline $\begin{array}{c}\text { Housework } \\
\text { husband }\end{array}$ & $\begin{array}{r}0.7764 * * \\
(0.0868)\end{array}$ & $\begin{array}{r}1.0000 \\
(0.0000)\end{array}$ & & \\
\hline Leisure wife & $\begin{array}{r}0.6622 * * \\
(0.0325)\end{array}$ & $\begin{array}{r}0.9733 * * \\
(0.0253)\end{array}$ & $\begin{array}{r}1.0000 \\
(0.0000)\end{array}$ & \\
\hline $\begin{array}{c}\text { Housework } \\
\text { wife }\end{array}$ & $\begin{array}{r}0.4754 * * \\
(0.0707)\end{array}$ & $\begin{array}{r}0.8905 * * \\
(0.0568)\end{array}$ & $\begin{array}{r}0.9483 * * \\
(0.0174)\end{array}$ & $\begin{array}{r}1.0000 \\
(0.0000) \\
\end{array}$ \\
\hline
\end{tabular}


Table 8. Model results: Marginal Utilities

Average marginal Proportion with negative marginal

\begin{tabular}{lll} 
& utility & utility \\
\hline Income & 2.7684 & 0.0000 \\
Husband's leisure & 0.5049 & 0.2662 \\
Husband's housework & 0.0952 & 0.3092 \\
Wife's leisure & 0.3489 & 0.4199 \\
Wife's housework & 0.3546 & 0.3480 \\
\hline
\end{tabular}

Note: Marginal utilities are computed keeping the other arguments of the couple's utility function constant (see Section 2). For simplicity, we denote the male partner as the 'husband' and the female partner as the 'wife', regardless of marital status. 
Table 9. Predicted and Actual Participation and Mean hours choices

\begin{tabular}{|c|c|c|c|c|}
\hline & \multicolumn{2}{|c|}{ Husband } & \multicolumn{2}{|c|}{ Wife } \\
\hline & Predicted & $\begin{array}{l}\text { Actual } \\
\text { Market }\end{array}$ & $\begin{array}{l}\text { Predicted } \\
\text { work }\end{array}$ & Actual \\
\hline 0 hours & 0.0542 & 0.0594 & 0.2938 & 0.2947 \\
\hline Mean hours & 6.8213 & 6.9106 & 4.3170 & 4.6285 \\
\hline \multicolumn{5}{|c|}{ Housework } \\
\hline 0 hours & 0.4016 & 0.4340 & 0.1681 & 0.1845 \\
\hline Mean hours & 1.2943 & 1.1345 & 4.6826 & 4.5636 \\
\hline
\end{tabular}


Table 10. Own and Cross Wage and Non-Labour Income Elasticities

\begin{tabular}{|c|c|c|c|c|}
\hline & \multicolumn{2}{|c|}{ Husbands } & \multicolumn{2}{|c|}{ Wives } \\
\hline & $\begin{array}{r}\text { Participation } \\
(\% \text {-points } \\
\text { change }) \\
\end{array}$ & $\begin{array}{r}\text { Average } \\
\text { Hours } \\
(\% \text {-change }) \\
\end{array}$ & $\begin{array}{r}\text { Participation } \\
(\% \text {-points } \\
\text { change }) \\
\end{array}$ & $\begin{array}{r}\text { Average } \\
\text { Hours } \\
\text { (\%-change })\end{array}$ \\
\hline & \multicolumn{2}{|c|}{ Market work } & \multicolumn{2}{|c|}{ Market work } \\
\hline \multicolumn{5}{|l|}{ Elasticities } \\
\hline a)Wife's net wage $1 \%$ increase & $\begin{array}{l}-0.0087 \\
\quad(0.0085)\end{array}$ & $\begin{array}{r}-0.1039 * * \\
(0.0099)\end{array}$ & $\begin{array}{r}0.2945 * * \\
(0.0123)\end{array}$ & $\begin{array}{r}0.5516 * * \\
(0.0371)\end{array}$ \\
\hline b)Husband's net wage $1 \%$ increase & $\begin{array}{r}0.1104 * * \\
(0.0062)\end{array}$ & $\begin{array}{r}0.2025 * * \\
(0.0184)\end{array}$ & $\begin{array}{r}-0.1213 * * \\
(0.0127)\end{array}$ & $\begin{array}{r}-0.3093 * * \\
(0.0254)\end{array}$ \\
\hline c)Non-labor income $1 \%$ increase & $\begin{array}{r}-0.0777 * * \\
(0.0079)\end{array}$ & $\begin{array}{r}-0.1252 * * \\
(0.0184)\end{array}$ & $\begin{array}{r}-0.1628 * * \\
(0.0203)\end{array}$ & $\begin{array}{r}-0.2479 * * \\
(0.0414)\end{array}$ \\
\hline & \multicolumn{2}{|c|}{ Housework } & \multicolumn{2}{|c|}{ Housework } \\
\hline \multicolumn{5}{|l|}{ Elasticities } \\
\hline a)Wife's net wage $1 \%$ increase & $\begin{array}{r}0.0412 * * \\
(0.0079)\end{array}$ & $\begin{array}{r}0.1168 * * \\
(0.0287)\end{array}$ & $\begin{array}{r}-0.1734 * * \\
(0.0081)\end{array}$ & $\begin{array}{r}-0.3623 * * \\
(0.0225)\end{array}$ \\
\hline b)Husband's net wage 1\% increase & $\begin{array}{r}-0.1940 * * \\
(0.0103)\end{array}$ & $\begin{array}{r}-0.3368 * * \\
(0.0564)\end{array}$ & $\begin{array}{r}0.0344 * * \\
(0.0071)\end{array}$ & $\begin{array}{r}0.0539 * \\
(0.0286)\end{array}$ \\
\hline c)Non-labor income $1 \%$ increase & $\begin{array}{r}-0.1093 * * \\
(0.0185)\end{array}$ & $\begin{array}{r}-0.3967 * * \\
(0.0568)\end{array}$ & $\begin{array}{l}-0.0050 \\
\quad(0.0133)\end{array}$ & $\begin{array}{l}0.0009 \\
(0.0296)\end{array}$ \\
\hline
\end{tabular}

Notes: **: significant at two-sided 5\% level; *: significant at two-sided 10\% level. Standard errors in parentheses. Interpretation: In response to an increase of $1 \%$ of all partnered women's net wage rates, female participation in paid work increases by $0.29 \%$-points and female hours of paid work increases by $0.55 \%$. For simplicity, we denote the male partner as the 'husband' and the female partner as the 'wife', regardless of marital status. 
Table 11. Simulated Effects of Income Tax Reforms

\begin{tabular}{|c|c|c|c|c|}
\hline & \multicolumn{2}{|c|}{ Husbands } & \multicolumn{2}{|c|}{ Wives } \\
\hline & $\begin{array}{r}\text { Participation } \\
(\% \text {-points } \\
\text { change }) \\
\end{array}$ & $\begin{array}{r}\text { Average } \\
\text { Hours } \\
(\% \text {-change })\end{array}$ & $\begin{array}{r}\text { Participation } \\
(\% \text {-points } \\
\text { change }) \\
\end{array}$ & $\begin{array}{r}\text { Average } \\
\text { Hours } \\
(\% \text {-change })\end{array}$ \\
\hline & \multicolumn{2}{|c|}{ Market work } & \multicolumn{2}{|c|}{ Market work } \\
\hline Income Taxation changes & & & & \\
\hline $\begin{array}{l}\text { Separate taxation of married } \\
\text { Couples }\end{array}$ & $\begin{array}{r}-0.1881 * \\
(0.1209)\end{array}$ & $\begin{array}{r}-0.7513 * * \\
(0.0066)\end{array}$ & $\begin{array}{r}2.3137 * \\
(1.3095)\end{array}$ & $\begin{array}{r}3.6599 * * \\
(0.0213)\end{array}$ \\
\hline $\begin{array}{l}\text { Joint taxation of cohabiting } \\
\text { Couples }\end{array}$ & $\begin{array}{l}0.1627 * \\
(0.1149)\end{array}$ & $1.0413 * *$ & $\begin{array}{r}-2.2528 * \\
(1.2848)\end{array}$ & $-3.5184 * *$ \\
\hline
\end{tabular}

Income Taxation changes

\section{Housework Housework}

Separate taxation of married $\quad 0.6473 * \quad 1.2767 * * \quad-0.8445 * * \quad-2.0147 * *$

$\begin{array}{lllll}\text { Couples } & (0.3770) & (0.0203) & (0.3822) & (0.0267)\end{array}$

Joint taxation of cohabiting $\quad-0.7949 * \quad-1.7559 * * \quad 1.1285 * \quad 2.1869 * *$

$\begin{array}{lllll}\text { Couples } & (0.4618) & (0.0261) & (0.5262) & (0.0259)\end{array}$

Notes: **: significant at two-sided 5\% level; *: significant at two-sided $10 \%$ level. Standard errors in parentheses. For each reform, we only consider couples who are affected by the reform (married couples for the first reform, cohabiting couples for the second reform). 
Table 12. Robustness Checks

\begin{tabular}{|c|c|c|c|c|c|c|c|}
\hline Net income elasticities & $\begin{array}{c}\text { Baseline } \\
\text { specification }\end{array}$ & $\begin{array}{l}\text { New } \\
\text { draws }\end{array}$ & $\begin{array}{l}\text { Reported } \\
\text { wages }\end{array}$ & $\begin{array}{l}\text { No } \\
\text { fixed } \\
\text { costs }\end{array}$ & $\begin{array}{l}\text { Part } \\
\text { time } \\
\text { costs }\end{array}$ & $\begin{array}{l}\text { Fixed \& } \\
\text { part time } \\
\text { costs }\end{array}$ & $\begin{array}{c}\text { No } \\
\text { house } \\
\text { work }\end{array}$ \\
\hline Market work husband & -0.1252 & -0.0418 & -0.2053 & -0.1813 & -0.0248 & -0.0418 & -0.1760 \\
\hline Housework husband & -0.3967 & -0.3347 & -0.4099 & -0.4276 & -0.2984 & -0.3347 & \\
\hline Market work wife & -0.2479 & -0.2488 & -0.2172 & -0.3172 & -0.2683 & -0.2488 & -0.1935 \\
\hline Housework wife & 0.0009 & 0.0115 & 0.0270 & 0.0155 & 0.0117 & 0.0115 & \\
\hline Husband's Net Wage elasticities & $\begin{array}{c}\text { Baseline } \\
\text { specification }\end{array}$ & $\begin{array}{l}\text { New } \\
\text { draws }\end{array}$ & $\begin{array}{c}\text { Reported } \\
\text { wages }\end{array}$ & $\begin{array}{l}\text { No } \\
\text { fixed } \\
\text { costs }\end{array}$ & $\begin{array}{l}\text { Part } \\
\text { time } \\
\text { costs }\end{array}$ & $\begin{array}{l}\text { Fixed \& } \\
\text { part time } \\
\text { costs }\end{array}$ & $\begin{array}{l}\text { No } \\
\text { house } \\
\text { work }\end{array}$ \\
\hline Market work husband & 0.2025 & 0.2124 & 0.2260 & 0.2465 & 0.1352 & 0.1258 & 0.2435 \\
\hline Housework husband & -0.3368 & -0.4087 & 0.0094 & -0.1265 & -0.1663 & -0.2391 & \\
\hline Market work wife & -0.3093 & -0.3049 & -0.2392 & -0.1348 & -0.2623 & -0.2086 & -0.3206 \\
\hline Housework wife & 0.0539 & 0.0217 & 0.0485 & 0.0178 & 0.0412 & 0.0138 & \\
\hline Wife's Net Wage elasticities & $\begin{array}{c}\text { Baseline } \\
\text { specification }\end{array}$ & $\begin{array}{c}\text { New } \\
\text { draws }\end{array}$ & $\begin{array}{c}\text { Reported } \\
\text { wages }\end{array}$ & $\begin{array}{l}\text { No } \\
\text { fixed } \\
\text { costs }\end{array}$ & $\begin{array}{l}\text { Part } \\
\text { time } \\
\text { costs }\end{array}$ & $\begin{array}{l}\text { Fixed \& } \\
\text { part time } \\
\text { costs }\end{array}$ & $\begin{array}{l}\text { No } \\
\text { house } \\
\text { work }\end{array}$ \\
\hline Market work husband & -0.1039 & -0.0938 & -0.0895 & -0.0194 & -0.0608 & -0.0416 & -0.1182 \\
\hline Housework husband & 0.1168 & 0.1050 & -0.0723 & -0.0549 & 0.0234 & 0.0395 & \\
\hline Market work wife & 0.5516 & 0.5567 & 0.4556 & 0.4640 & 0.4446 & 0.3829 & 0.6062 \\
\hline Housework wife & -0.3623 & -0.3191 & -0.3749 & -0.3597 & -0.2701 & -0.2499 & \\
\hline $\begin{array}{l}\text { Separate income taxation } \\
\text { (married couples only) }\end{array}$ & $\begin{array}{c}\text { Baseline } \\
\text { specification }\end{array}$ & $\begin{array}{l}\text { New } \\
\text { draws }\end{array}$ & $\begin{array}{c}\text { Reported } \\
\text { wages }\end{array}$ & $\begin{array}{l}\text { No } \\
\text { fixed } \\
\text { costs }\end{array}$ & $\begin{array}{l}\text { Part } \\
\text { time } \\
\text { costs }\end{array}$ & $\begin{array}{l}\text { Fixed \& } \\
\text { part time } \\
\text { costs }\end{array}$ & $\begin{array}{l}\text { No } \\
\text { house } \\
\text { work }\end{array}$ \\
\hline Market work husband & -0.7513 & -0.7516 & -0.6028 & -0.6012 & -0.4228 & -0.3633 & -0.8444 \\
\hline Housework husband & 1.2767 & 1.4253 & -0.0685 & 0.2611 & 0.4366 & 0.7650 & \\
\hline Market work wife & 3.6599 & 3.6142 & 2.8387 & 2.6277 & 3.0729 & 2.6124 & 3.7567 \\
\hline Housework wife & -2.0147 & -1.6795 & -1.9196 & -1.7142 & -1.5135 & -1.3249 & \\
\hline
\end{tabular}

Notes: Each column presents selected robustness checks results (see Section 5). The first column gives the baseline results (as in Tables 10 and 11). 
Appendix A: Heckman Selection Models for Hourly Wages

Table A1. Heckman selection model for the male wage rate

\begin{tabular}{|c|c|c|c|}
\hline \multirow{2}{*}{$\begin{array}{l}\text { Hourly Wage Equation } \\
\text { Potential experience }\end{array}$} & \multirow{2}{*}{$\begin{array}{l}\text { Coefficient } \\
0.0457\end{array}$} & \multicolumn{2}{|c|}{ Standard error } \\
\hline & & 0.0038 & $* *$ \\
\hline Potential experience squared & -0.0005 & 0.0001 & $* *$ \\
\hline Elementary school & 0.0635 & 0.0359 & $*$ \\
\hline Lower secondary, vocational & 0.3110 & 0.0491 & $* *$ \\
\hline Lower secondary & 0.2334 & 0.0376 & $* *$ \\
\hline Upper secondary vocational & 0.4805 & 0.0553 & $* *$ \\
\hline Upper secondary & 0.4998 & 0.0565 & $* *$ \\
\hline University short degree & 0.7352 & 0.0580 & $* *$ \\
\hline University degree or higher & 1.1217 & 0.0527 & ** \\
\hline Dummy Single & $-\mathbf{0 . 1 0 3 7}$ & 0.0395 & $* *$ \\
\hline Dummy Cohabiting & -0.0879 & 0.0296 & $* *$ \\
\hline Constant & 2.9003 & 0.1021 & $* *$ \\
\hline \multicolumn{4}{|l|}{ Selection Equation } \\
\hline Potential experience & 0.0278 & 0.0160 & $*$ \\
\hline Potential experience squared & -0.0006 & 0.0002 & $* *$ \\
\hline Elementary school & 0.1610 & 0.1327 & \\
\hline Lower secondary, vocational & 0.4884 & 0.1619 & $* *$ \\
\hline Lower secondary & 0.3575 & 0.1074 & $* *$ \\
\hline Upper secondary vocational & 0.5912 & 0.1959 & $* *$ \\
\hline Upper secondary & 0.6287 & 0.1992 & $* *$ \\
\hline University short degree & 0.7709 & 0.1699 & $* *$ \\
\hline University degree or higher & 0.6137 & 0.1601 & $* *$ \\
\hline Dummy Single & -0.5950 & 0.1073 & $* *$ \\
\hline Dummy Cohabiting & -0.3696 & 0.0929 & $* *$ \\
\hline Dummy child <3 years & -0.1824 & 0.1051 & $*$ \\
\hline Dummy child 3-5 years & -0.0921 & 0.1076 & \\
\hline Dummy child 6-10 years & 0.0398 & 0.0947 & \\
\hline Dummy child 11-16 years & 0.0179 & 0.0936 & \\
\hline Number of adults in the household & 0.0410 & 0.0563 & \\
\hline Constant & 0.6562 & 0.2990 & $* *$ \\
\hline Inverse Mills Ratio & -0.0224 & 0.1732 & \\
\hline Correlation between the error terms & -0.0713 & & \\
\hline St. deviation error wage equation & 0.3139 & & \\
\hline Observations & 2193 & & \\
\hline
\end{tabular}


Table A2. Heckman selection model for the female wage rate.

\begin{tabular}{|c|c|c|c|}
\hline \multirow{2}{*}{$\begin{array}{l}\text { Hourly Wage Equation } \\
\text { Potential experience }\end{array}$} & \multirow{2}{*}{$\begin{array}{l}\text { Coefficient } \\
0.0409\end{array}$} & \multicolumn{2}{|c|}{ Standard error } \\
\hline & & 0.0036 & $* *$ \\
\hline Potential experience squared & -0.0004 & 0.0001 & $* *$ \\
\hline Elementary school & 0.0982 & 0.0364 & $* *$ \\
\hline Lower secondary, vocational & 0.2714 & $\mathbf{0 . 0 3 9 0}$ & $* *$ \\
\hline Lower secondary & 0.2960 & 0.0339 & $* *$ \\
\hline Upper secondary vocational & 0.4291 & 0.0471 & $* *$ \\
\hline Upper secondary & 0.5536 & 0.0414 & $* *$ \\
\hline University short degree & 0.8458 & 0.0421 & $* *$ \\
\hline University degree or higher & 1.2190 & 0.0447 & $* *$ \\
\hline Constant & 2.7120 & 0.0775 & $* *$ \\
\hline \multicolumn{4}{|l|}{ Selection Equation } \\
\hline Potential experience & 0.0606 & 0.0119 & $* *$ \\
\hline Potential experience squared & -0.0012 & 0.0002 & $* *$ \\
\hline Elementary school & 0.3586 & 0.0927 & $* *$ \\
\hline Lower secondary, vocational & 0.4606 & 0.1011 & $* *$ \\
\hline Lower secondary & 0.4097 & 0.0833 & $* *$ \\
\hline Upper secondary vocational & 0.6459 & 0.1339 & $* *$ \\
\hline Upper secondary & $\mathbf{0 . 5 5 2 7}$ & 0.1100 & $* *$ \\
\hline University short degree & 0.8452 & 0.1088 & $* *$ \\
\hline University degree or higher & $\mathbf{0 . 8 3 7 0}$ & 0.1211 & $* *$ \\
\hline Dummy Single & 0.4280 & 0.0720 & $* *$ \\
\hline Dummy Cohabiting & 0.1811 & 0.0718 & $* *$ \\
\hline Dummy child $<3$ years & -0.5643 & 0.0776 & $* *$ \\
\hline Dummy child 3-5 years & -0.4890 & 0.0756 & $* *$ \\
\hline Dummy child 6-10 years & -0.3029 & 0.0626 & $* *$ \\
\hline Dummy child 11-16 years & -0.1165 & 0.0607 & $*$ \\
\hline Number of adults in the household & -0.0655 & 0.0361 & $*$ \\
\hline Constant & -0.5646 & 0.2163 & $* *$ \\
\hline Inverse Mills Ratio & 0.0940 & 0.0419 & $* *$ \\
\hline Correlation between the error terms & 0.2879 & & \\
\hline Standard deviation error wage equation & 0.3264 & & \\
\hline Observations & 3406 & & \\
\hline
\end{tabular}

**: significant at two-sided 5\% level; *: significant at two-sided $10 \%$ level.

Regional controls are included in both equations. Observations that did not complete elementary school are often foreigners. The dummies for marital status were (jointly) not statistically significant in the wage equation and thus, they work as valid exclusion restrictions for the selection equation. 